\title{
AMBIENTAL VOLATILE ORGANIC COMPOUNDS IN THE MEGACITY OF SÃO PAULO
}

Leila Droprinchinski Martins*, Maria de Fátima Andrade and Rita Yuri Ynoue

Departamento de Ciências Atmosféricas, Instituto de Astronomia, Geofísica e Ciências Atmosféricas, Universidade de São Paulo, Rua do Matão, 1226, 05508-090 São Paulo - SP, Brasil

Édler Lins de Albuquerque and Edson Tomaz

Departamento de Processos Químicos, Faculdade de Engenharia Química, Universidade Estadual de Campinas, Campus Zeferino Vaz, CP 6066, 13083-970 Campinas - SP, Brasil

Pérola de Castro Vasconcellos

Instituto de Química, Universidade de São Paulo, Av. Prof. Lineu Prestes, 748, 05508-900 São Paulo - SP, Brasil

Recebido em 19/11/07; aceito em 2/6/08; publicado na web em 5/11/08

\begin{abstract}
In order to characterize the composition of the main urban air organic compounds in the megacity of Sao Paulo, analysis of samples collected during the winter of 2003 downtown was carried out. The samplings were performed on the roof of a building in the commercial center of São Paulo. Hydrocarbons and carbonyls compounds were collected on August 4, 5 and 6. Comparing to previous data, the concentration of hydrocarbons presented no decrease in the concentration, except for the aldehydes, which decreased when compared to previous data. Among the HCs species analyzed, the highest concentrations observed were those of toluene ( $7.5 \pm 3.4$ ppbv), n-decane ( $3.2 \pm 2.0 \mathrm{ppbv})$, benzene ( $2.7 \pm 1.4 \mathrm{ppbv})$ and 1,3,5-trimethylbenzene ( $2.2 \pm 1.5 \mathrm{ppbv})$.
\end{abstract}

Keywords: hydrocarbons; vehicular emission; urban air quality.

\section{INTRODUCTION}

Atmospheric science, particularly, atmospheric chemistry and air quality management are topics that are receiving increasing attention from policy makers and scientific communities. Typically the research and management initiatives have been motivated by severe air pollution problems as those daily experienced by the inhabitants of crowded cities. The Metropolitan Area of São Paulo (MASP) is the largest industrialized region in Latin America localized in a plate $\left(23.54^{\circ} \mathrm{S}\right.$ and $\left.46.64^{\circ} \mathrm{W}\right)$ and is constituted by 38 municipalities and the city of São Paulo (Figure 1). It has an area of $8,051 \mathrm{~km}^{2}$ with a population higher than 17 million inhabitants distributed heterogeneously and concentrated in $1,747 \mathrm{~km}^{2}$.

Megacities are the largest urban conglomerates in the world (with a population $\geq 10$ million inhabitants), but not necessarily the most polluted. The footprint of a megacity encompasses not only the area located within a city's political boundaries, but also their suburbs and, in turn, it is affected by wastes and pollutants. ${ }^{2}$ Studies of World Health Organization (WHO) showed that seven megacities have three or more pollutants that exceed the standard for protective of health: Mexico City, Beijing, Cairo, Jacarta, Los Angeles, São Paulo and Moscow. There is a great necessity of implementing control strategies in almost all megacities in the world, focusing the improvement of air quality.

Currently in MASP there are approximately 7.8 million vehicles, which are responsible for the largest fraction of anthropogenic gases emission in the region. ${ }^{1}$ Approximately $76.3 \%$ of the light-duty vehicles burn a mixture of gasoline and ethanol (20-25\% in volume of ethanol - referred to as gasohol), and $17.2 \%$ use hydrated ethanol ( $95 \%$ ethanol $+5 \%$ water). The addition of ethanol to motor vehicle fuels reduces carbon monoxide (CO) but increases aldehyde emissions (especially acetaldehyde), inducing a unique photochemical smog problem in urban areas. Moreover the numbers of vehicles that burn alternative fuel in MASP has increased. Since 2003 dual engine

*e-mail: leiladro@model.iag.usp.br light-duty vehicles (use both gasohol and hydrated ethanol) started circulating in MASP. Due to a great and constant change of types of vehicles and fuel in Brazil it becomes necessary frequent measurements of pollutants emission and ambient air quality. However few measurements for São Paulo are reported in literature. ${ }^{3-5}$

The Volatile Organic Compounds (VOCs) characterization in the atmosphere is important not only because they are precursors of ozone, but also due to their possible adverse health effects (e.g. benzene, 1,3-butadiene and chlorinated hydrocarbons). In addition, the formaldehyde and acetaldehyde are the most important carbonyls with respect to reaction with $\mathrm{OH}$ (hydroxyl radical) and they present possible harmful health effects. Further, the photochemical oxidation of aromatic aldehydes, leads to peroxybenzoyl nitrates, which have received attention as severe eye irritants and as mutagens. ${ }^{6}$

The atmospheric chemistry in the tropics and subtropics is not well known and the study of atmospheric emission from megacities in these regions will have special significance. ${ }^{7}$ The estimate of influence of megacities in regional-global air chemistry and climate is still a challenge mainly because of lack of data in countries of Asia, Africa and South America. In this direction the objective of this work was to quantify the main VOCs in the atmosphere of São Paulo (in relation to human health and potential ozone production) and to compare the present levels with past values reported for MASP. Additionally, the data can be used to validation the air quality models.

\section{EXPERIMENTAL}

\section{Measurements and analytical methods}

Field measurements of hydrocarbons (HCs) and carbonyls compounds were carried out on workdays on August 4, 5 and 6, 2003. The site was located on the rooftop of a building (approximately 14 $\mathrm{m}$ from surface) in the downtown area of São Paulo city at $23.55^{\circ} \mathrm{S}$ and $46.63^{\circ} \mathrm{O}$. Additionally measurements of $\mathrm{CO}, \mathrm{NO}_{x}$, temperature, wind speed, wind direction and humidity were provided by the 
Companhia de Tecnologia e Saneamento Ambiental (CETESB, São Paulo Environmental Regulation Agency).

The HCs were sampled in a cartridge containing Tenax TA adsorbent (Supelco, Bellefonte, PA, USA), using an automated sequential tube sampler (STS-25; Perkin-Elmer, Norwalk, CT, USA). The cartridges were previously tested and kept in freezer. Four hour-samples were collected continuously from 8:00 am of August 4 to 4:00 pm of August 6. The airflow into cartridges changed from 35 to $90 \mathrm{~mL} \mathrm{~min}{ }^{-1}$. The samples were analyzed at the State University of Campinas (São Paulo, Brazil) using a thermal desorber (ATD-400; Perkin-Elmer) coupled to GC-FID system (Autosystem XL; Perkin-Elmer). The HCs were separated on a column PE-624 (30-m length; 0.25-mm ID; 1.4- $\mu \mathrm{m}$ film thickness). The analysis conditions used were as follows: carrier gas: Helium at flow of $1,7 \mathrm{~mL} \mathrm{~min}{ }^{-1}$; desorption temperature: $300{ }^{\circ} \mathrm{C}$; desorption flow: $60 \mathrm{~mL} \mathrm{~min}^{-1}$; split: $25 \mathrm{~mL} \mathrm{~min}^{-1}$; temperature program: $40-140^{\circ} \mathrm{C}$ at $5{ }^{\circ} \mathrm{C} \mathrm{min}^{-1}$; detector temperature: $250^{\circ} \mathrm{C}$; Flow of $\mathrm{H}_{2}: 45 \mathrm{~mL} \mathrm{~min}^{-1}$ and synthetic airflow: $420 \mathrm{~mL} \mathrm{~min}^{-1} .8$

The compounds analyzed were: benzene, n-heptane, toluene, chlorobenzene, ethylbenzene, i-propylbenzene (cumene), o-xylene, $\mathrm{m}+\mathrm{p}$-xylene, 1,3,5-trimethylbenzene (1,3,5-TMB) and n-decane.

Carbonyls compounds were sampled for $2 \mathrm{~h}$ (from 8:00 am until 12:00 pm and 2:00 pm until 6:00 pm). The ambient air was drawn into a cartridge (Sep-Pak DNPH-Silica; Waters, Milford, MA, USA) at 2 L $\mathrm{min}^{-1}$. The ambient air was filtered using ozone scrubber filters (Waters) to avoid artifact formation on ambient samples. After sample collection, the silica-DNPH cartridges were extracted with acetonitrile into a $5 \mathrm{~mL}$ volumetric flask. The analysis of carbonyls was performed at Chemistry Institute at University of São Paulo using a high-performance liquid chromatography (HPLC) system (SCL-10A; Shimadzu, Tokyo, Japan). The analytical apparatus included a Rheodyne injection valve with a 20- $\mu \mathrm{L}$ sample loop, two pumps (LC-10AD; Shimadzu) and an UV/ visible detector (SPD-10AV UV-Vis; Shimadzu) at $365 \mathrm{~nm}$. Hydrazones were separated using a Shimadzu Shim-pack CLC-ODS column (15 $\mathrm{cm} \times 6 \mathrm{~mm} \times 5 \mu \mathrm{m})$ connected to a Shim-pack G-ODS pre-column operated at ambient temperature $\left(25^{\circ} \mathrm{C}\right)$. A gradient elution method was employed with solvents $\mathrm{A}\left(20: 20: 60\right.$ by volume $\left.\mathrm{CH}_{3} \mathrm{CN}-\mathrm{THF}-\mathrm{H}_{2} \mathrm{O}\right)$ and $\mathrm{B}\left(100 \% \mathrm{CH}_{3} \mathrm{CN}\right)$. The gradient initiated linearly from 10 to $30 \%$ $\mathrm{B}$ in $17 \mathrm{~min}$, remained at $30 \% \mathrm{~B}$ for $6 \mathrm{~min}$, then reached $90 \% \mathrm{~B}$ in 7 min. The mobile phase flow rate was $1.3 \mathrm{~mL} \mathrm{~min}^{-1}$. Concentrations of carbonyls in air samples were calculated using the calibration data of the external carbonyl DNPH standards..$^{5,9,10}$

\section{Meteorological conditions}

According to Oliveira et al., ${ }^{11}$ the climate of São Paulo city is characterized by a dry winter during June-August and a wet summer during December-March. The minimum values of daily monthlyaveraged temperature and relative humidity occur in July and August ( $16{ }^{\circ} \mathrm{C}$ and $74 \%$, respectively), and the minimum monthly-accumulated precipitation occurs in August $(35 \mathrm{~mm})$. Combined effects of the geographic position and relative intensity of the semi-stationary South-Atlantic Anticyclone and Continental low-pressure systems control the seasonal variation of surface winds in São Paulo city. They induce surface winds from NE-E during the winter and N-NE during the summer. In addition, this pattern is frequently affected by winter synoptic scale systems, such as cold fronts, and by mesoscale sytems, such as sea breeze fronts. ${ }^{12}$

During the measurement period, the prevailing winds were from northeast with wind speed varying from calm wind to $3.7 \mathrm{~m} \mathrm{~s}^{-1}$, with a mean value of $0.93 \pm 0.97 \mathrm{~m} \mathrm{~s}^{-1}$. The temperature varied from 13.0 to $27.5^{\circ} \mathrm{C}$ and the humidity from 99.4 to $23.8 \%$. During the winter the precipitation is mostly associated with cold fronts. On August 4 and 5, pre-frontal conditions prevailed, with no precipitation, but with large diurnal variation of humidity and temperature. On August 6 a cold front arrived in São Paulo and in the end of the afternoon the sky was completely cloudy and no precipitation was observed.

\section{RESULTS AND DISCUSSION}

São Paulo city has chaotic traffic of vehicles with long periods of traffic jams. Figure 1 presents the workday profile of traffic obtained from measurements of $\mathrm{CO}$ concentrations inside the tunnel. ${ }^{13}$ The emission of $\mathrm{CO}$ is associated to vehicles traffic, concentrated mainly at rush hours. Table 1 presents the HCs ambient concentrations obtained in this study. The higher concentrations occurred on days 4 and 5 in the morning and in the end of the afternoon. This profile reflects the conditions of traffic in São Paulo, which has higher emissions between

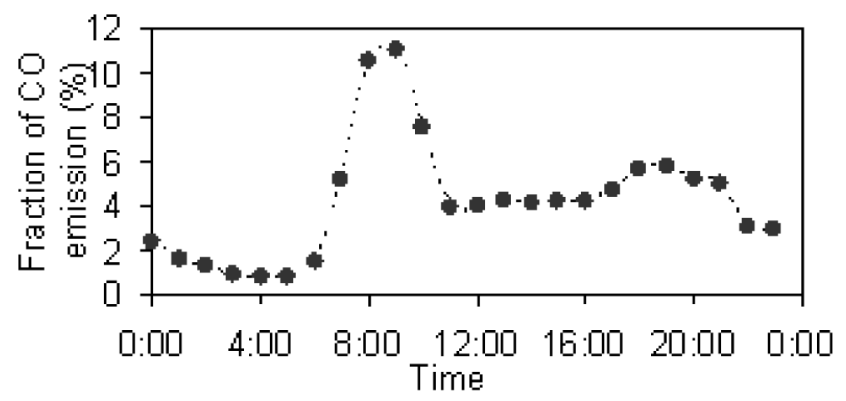

Figure 1. Profile of workday traffic in São Paulo city

Table 1. Hydrocarbons compounds concentration in downtown of São Paulo city (ppbv)

\begin{tabular}{|c|c|c|c|c|c|c|c|c|c|c|c|c|c|c|}
\hline \multirow{2}{*}{$\begin{array}{l}\text { Date } \\
\text { Time } \\
\text { Compound }\end{array}$} & \multicolumn{4}{|c|}{$04 / 08$} & \multicolumn{6}{|c|}{$05 / 08$} & \multicolumn{4}{|c|}{$06 / 08$} \\
\hline & $\begin{array}{c}07: 55- \\
11: 55\end{array}$ & $\begin{array}{c}12: 25- \\
16: 25\end{array}$ & $\begin{array}{l}16: 25- \\
20: 25\end{array}$ & $\begin{array}{c}20: 25- \\
00: 25\end{array}$ & $\begin{array}{c}00: 25- \\
04: 25\end{array}$ & $\begin{array}{c}04: 25- \\
08: 08\end{array}$ & $\begin{array}{c}08: 25- \\
12: 25\end{array}$ & $\begin{array}{c}12: 25- \\
16: 25\end{array}$ & $\begin{array}{l}16: 25- \\
20: 25\end{array}$ & $\begin{array}{l}20: 25- \\
00: 25\end{array}$ & $\begin{array}{c}00: 25- \\
04: 25\end{array}$ & $\begin{array}{c}04: 25- \\
08: 15\end{array}$ & $\begin{array}{c}08: 20- \\
12: 20\end{array}$ & $\begin{array}{c}12: 20- \\
16: 20\end{array}$ \\
\hline Benzene & 4.32 & 2.36 & 3.11 & 5.47 & 3.29 & 2.30 & 2.26 & 0.80 & 3.51 & 4.09 & 1.31 & 1.47 & 2.95 & 0.89 \\
\hline n-Heptane & 0.39 & 0.38 & 0.61 & 0.66 & 0.23 & 0.18 & 0.06 & - & 0.30 & 0.27 & - & 0.09 & 0.31 & - \\
\hline Toluene & 14.12 & 5.97 & 7.92 & 13.15 & 9.65 & 7.59 & 4.87 & 3.73 & 8.54 & 7.02 & 5.00 & 7.43 & 7.89 & 1.60 \\
\hline Cl-benzene & 1.65 & 0.88 & 0.90 & 0.32 & 0.44 & 0.38 & 0.23 & 0.09 & 0.25 & 0.19 & 0.06 & 0.08 & 0.11 & 0.03 \\
\hline Ethylbenzene & 1.21 & 1.03 & 1.07 & 1.15 & 1.11 & 0.71 & 0.36 & 0.04 & 0.85 & 0.59 & 0.16 & 0.41 & 0.74 & 0.10 \\
\hline m+p-Xylene & 2.32 & 0.40 & 1.93 & 2.32 & 1.97 & 1.28 & 0.76 & 0.13 & 1.69 & 1.06 & 0.39 & 0.78 & 1.41 & 0.31 \\
\hline o-Xylene & 1.72 & 0.52 & 0.36 & 0.97 & 0.56 & 0.33 & 0.51 & 0.14 & 0.56 & 0.28 & - & 0.08 & 0.62 & - \\
\hline Cumene & 1.01 & 1.07 & 0.02 & 0.80 & 0.44 & 0.05 & 0.28 & - & 0.34 & 0.25 & - & - & 0.58 & - \\
\hline 1,3,5-TMB & 5.21 & 4.33 & 1.64 & 4.21 & 3.20 & 1.07 & 1.82 & 0.69 & 1.90 & 1.91 & 0.33 & 0.91 & 2.66 & 0.70 \\
\hline n-Decane & 6.88 & 6.50 & 2.93 & 5.59 & 4.63 & 2.95 & 2.67 & 0.94 & 2.43 & 2.60 & 1.11 & 1.61 & 3.24 & 0.44 \\
\hline
\end{tabular}


7:00 and 9:00 am, and 5:00 to 9:00 pm. Other factors also affect the concentration as the photochemical activity which is higher during the daylight and it increases the boundary layer, providing a larger volume for the dilution of pollutants.

Figure 2 presents sample profiles for benzene, toluene and $m+p$ xylenes during the studied period. The decrease in the concentrations on August 6 was related to the weather conditions. Among the HCs species analyzed, the highest concentrations observed were those of toluene $(7.5 \pm 3.4 \mathrm{ppbv}), \mathrm{n}$-decane $(3.2 \pm 2.0 \mathrm{ppbv})$, benzene $(2.7 \pm$ $1.4 \mathrm{ppbv})$ and 1,3,5-trimethylbenzene (2.2 $\pm 1.5 \mathrm{ppbv})$.

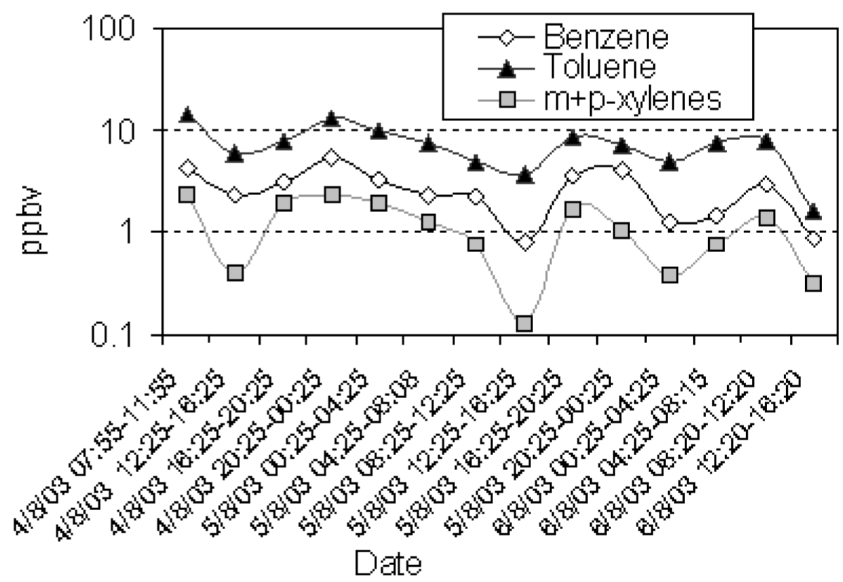

Figure 2. Benzene, toluene and $m+p$ xylenes concentrations in downtown of São Paulo

The ratio benzene/toluene can be used to estimate if the source is vehicular or not. ${ }^{3}$ When the ratio benzene to toluene (ration B:T) is between 0.2 and 0.5 , the samples can be considered as indicative of predominant vehicular emissions. Considering the samples analyzed in this study the ratio B:T obtained lies between 0.18 and $0.49(0.32$ $\pm 0.10)$. These results indicated that the vehicular source is the predominant source of these compounds in São Paulo as expected.

We further investigated the age of pollutants plume, which can collaborate in understanding the behavior of the compounds. The ratio xylene/ethylbenzene $(\mathrm{X} / \mathrm{E})$ can be indicative of the urban plume photochemical age..$^{14,15}$ The X/E ratio for different sources, obtained from many different studies, is relatively constant varying from 2.8 to 4.6. ${ }^{15}$ However due to the lack of measurements in São Paulo (or Brazil) reported in literature, it was not included in this statistic.

The mean ratio X/E found in São Paulo was of $2.0 \pm 0.7$. This value suggests that plume was new and relatively near the local source influence, in agreement with the characteristics of the site, in which the air reaching the samplers is well mixed. In addition, the ratios $\mathrm{X} / \mathrm{E}$ from other studies performed in São Paulo were calculated, with values of 3.0 (data from 1996) and 2.3 (data from 1998). ${ }^{3,4}$

The correlation among the typical HCs in urban air was performed. The species benzene, ethylbenzene, toluene and $m+p$-xylenes presented a high correlation $\left(\mathrm{R}^{2} 0.7-0.8\right)$, indicating that they are probably emitted by the same source.

Table 2 presents the carbonyls compounds analyzed. Acetaldehyde and formaldehyde were the most abundant carbonyls species. The carbonyls compounds are very important for ozone formation, mainly acetaldehyde and formaldehyde, which are emitted in general by alcohol and oil fuel exhausts respectively.

The concentrations of formaldehyde and acetaldehyde during workday are illustrated in Figure 3. It is observed that the highest concentrations occurred in the early morning and late afternoon, probably, due to the combination of higher traffic emission and lower planetary boundary layer. There is also photochemical formation of secondary pollutants, mainly formaldehyde, from the oxidation of $\mathrm{CO}$ and HCs. On August 6 due to the arrival of a cold front and the increase of humidity at the end of the day, this behavior could not be observed. In addition a peak of concentration was observed in the morning samples on August 6. This peak can be attributed to the meteorological conditions, that associated to the peak of traffic emission contribute for higher concentrations. This behavior was slightly observed for the HCs.

The number of monitoring stations that provide non-methane hydrocarbons (NMHC) concentrations in MASP is scarce. Table 3 shows some statistics estimates for NMHC concentrations, measured at MASP monitoring sites, from 2000 to 2004 provided by CETESB. The differences of concentration among sites are related to source characteristics of sites. Park D. Pedro II is localized downtown São Paulo city and the main source of NMHC is associated to vehicles. On the other hand São Caetano do Sul site is localized to southeast of São Paulo, where there is a large industry activity, contributing to increase the levels of NMHC.

In Figure 4 it is presented the daily profile for $\mathrm{CO}$ and $\mathrm{NO}_{x}$ obtained from CETESB air quality network during the sampling period. The

Table 2. Carbonyls compounds concentrations in downtown of São Paulo city (ppbv)

\begin{tabular}{|c|c|c|c|c|c|c|c|c|c|c|c|c|}
\hline \multirow{2}{*}{$\begin{array}{l}\text { Date } \\
\text { Time } \\
\text { Compound }\end{array}$} & \multicolumn{4}{|c|}{$04 / 08$} & \multicolumn{4}{|c|}{$05 / 08$} & \multicolumn{4}{|c|}{ 06/08 } \\
\hline & $\begin{array}{l}8: 07- \\
10: 00\end{array}$ & $\begin{array}{c}10: 04- \\
11: 58\end{array}$ & $\begin{array}{c}13: 59- \\
16: 00\end{array}$ & $\begin{array}{c}16: 08- \\
18: 01\end{array}$ & $\begin{array}{l}8: 04- \\
10: 05\end{array}$ & $\begin{array}{c}10: 09- \\
12: 09\end{array}$ & $\begin{array}{c}13: 57- \\
16: 02\end{array}$ & $\begin{array}{c}16: 04- \\
18: 04\end{array}$ & $\begin{array}{l}8: 00- \\
10: 00\end{array}$ & $\begin{array}{c}10: 01- \\
12: 02\end{array}$ & $\begin{array}{c}14: 00- \\
15: 59\end{array}$ & $\begin{array}{c}16: 00 \\
17: 59 \\
\end{array}$ \\
\hline Formaldehyde & 2.91 & 2.45 & 2.00 & 4.67 & 4.32 & 2.21 & 3.16 & 4.92 & 7.95 & 8.08 & 4.84 & 5.08 \\
\hline Acetaldehyde & 3.19 & 1.91 & 1.44 & 2.71 & 3.30 & 0.99 & 1.17 & 2.00 & 9.18 & 4.34 & 1.52 & 2.05 \\
\hline Acetone & 1.47 & 0.30 & 0.45 & 1.10 & 1.06 & 0.85 & 1.17 & 0.95 & 3.56 & 1.30 & 0.56 & 0.71 \\
\hline Acroleyne & 0.10 & 0.06 & - & - & 0.12 & - & - & 0.06 & 0.28 & 0.13 & 0.06 & 0.14 \\
\hline Propionaldehyde & 0.25 & 0.21 & 0.16 & 0.27 & 0.27 & 0.08 & 0.10 & 0.15 & 0.64 & 0.33 & 0.11 & 0.16 \\
\hline Crotonaldehyde & - & - & - & - & - & - & - & - & - & - & 0.09 & 0.11 \\
\hline 2-Butanone & 0.78 & 0.37 & 0.20 & 0.42 & 0.31 & 0.17 & 0.30 & 0.28 & 0.75 & 0.43 & 0.19 & 0.18 \\
\hline Metacroleyne & - & - & - & - & 0.04 & 0.04 & 0.05 & 0.06 & 0.11 & 0.06 & 0.03 & 0.03 \\
\hline n-Butinaldehyde & - & - & - & - & - & - & - & - & 0.41 & 0.20 & 0.13 & 0.15 \\
\hline Benzaldehyde & 0.11 & 0.05 & 0.04 & 0.09 & 0.07 & 0.05 & 0.03 & 0.07 & 0.18 & 0.10 & 0.06 & 0.06 \\
\hline Valeraldehyde & - & - & - & - & 0.14 & - & - & - & 0.11 & - & - & 0.18 \\
\hline m-Tolualdehyde & - & - & - & - & 0.05 & - & - & - & - & - & - & 0.05 \\
\hline Hexaldehyde & 0.12 & 0.04 & 0.08 & 0.13 & 0.04 & 0.05 & 0.03 & 0.04 & 0.13 & 0.05 & 0.03 & 0.05 \\
\hline
\end{tabular}


Table 3. Non-methane hydrocarbons in ppmC measured in MASP

\begin{tabular}{|c|c|c|c|c|c|c|c|c|c|c|c|c|c|c|c|}
\hline \multirow{3}{*}{ Sampling location } & \multicolumn{15}{|c|}{ Year } \\
\hline & \multicolumn{3}{|c|}{2000} & \multicolumn{3}{|c|}{2001} & \multicolumn{3}{|c|}{2002} & \multicolumn{3}{|c|}{2003} & \multicolumn{3}{|c|}{2004} \\
\hline & $\mathrm{N}^{\mathrm{a}}$ & Average & $\begin{array}{l}\text { Max'. } \\
\text { hourly }\end{array}$ & $\mathrm{N}$ & Average & $\begin{array}{l}\text { Max. } \\
\text { hourly }\end{array}$ & $\mathrm{N}$ & Average & $\begin{array}{l}\text { Max. } \\
\text { hourly }\end{array}$ & $\mathrm{N}$ & Average & $\begin{array}{l}\text { Max. } \\
\text { hourly }\end{array}$ & $\mathrm{N}$ & Average & $\begin{array}{l}\text { Max. } \\
\text { hourly }\end{array}$ \\
\hline $\begin{array}{l}\text { Park D. Pedro II } \\
(-23.545,-46.629)\end{array}$ & 307 & 0.78 & 6.66 & 277 & 0.62 & 6.82 & 258 & 0.53 & 5.91 & - & - & - & - & - & - \\
\hline $\begin{array}{l}\text { São Caetano do Sul } \\
(-23.617,-46.556)\end{array}$ & 296 & 0.66 & 16.85 & 243 & 0.74 & 13.47 & 245 & 0.75 & 14.09 & 139 & 0.57 & 8.47 & 160 & 0.62 & 9.87 \\
\hline
\end{tabular}

${ }^{\mathrm{a}} \mathrm{N}=$ Number of valid data. ${ }^{\mathrm{b}} \mathrm{Max} .=$ refer to hourly maximum
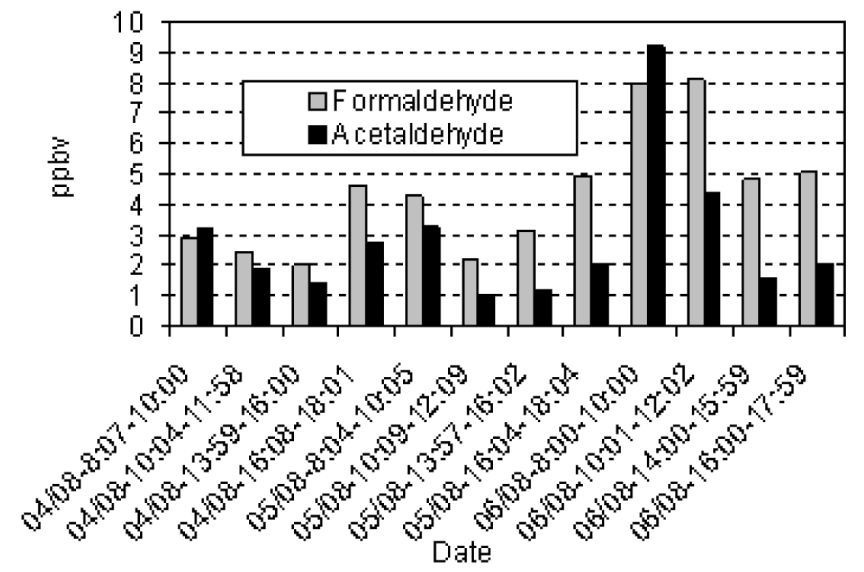

Figure 3. Formaldehyde and acetaldehyde concentrations in downtown of São Paulo

profile of $\mathrm{CO}$ and $\mathrm{NO}_{x}$ presented excellent agreement. The correlation between $\mathrm{NO}_{x}$ and acetaldehyde was of $0.72\left(\mathrm{R}^{2}\right)$, being indicative that the main source of acetaldehyde is the vehicular emission. In addition, indicating that the site is representative of the São Paulo atmosphere.

The values of ambient HCs concentrations measured in São Paulo, in this study, are in general higher than those observed in the USA, in agreement with previous results from 1998, found by Colón et al. ${ }^{4}$ for São Paulo. On the other hand, ambient VOCs concentrations reported for Asian cities (specifically for toluene, ethylbenzene and xylenes) are higher than for South American cities (Gee and Sollars, 1998). In Table 4 it is presented a comparison among the levels of selected HCs concentrations measured in different years for São Paulo city, including the HCs from this work. . $^{3,4}$

There is a strong compliance to reduce benzene emissions in urban air emissions because of its carcinogenicity. The WHO recommends to avoid exposition to benzene, even at lower concentrations. In addition most alkenes and aromatics compounds have influence

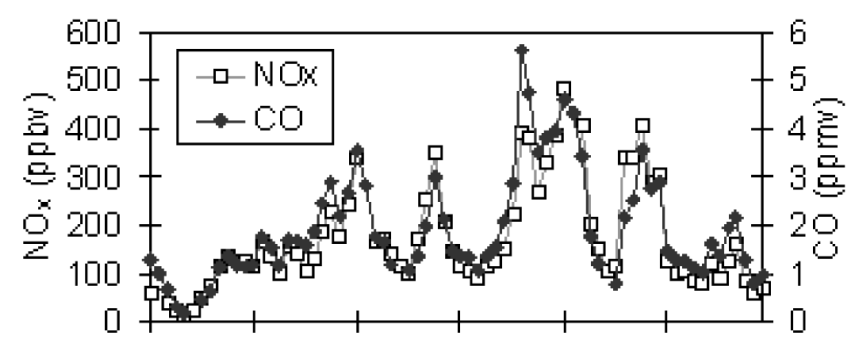

4/8/03 4/8/03 5/8/03 5/8/03 6/8/03 6/8/03 0:00 12:00 0:00 12:00 $0: 00 \quad 12: 00$ Date

Figure 4. Profile of $\mathrm{NO}_{x}$ and $\mathrm{CO}$ concentrations in downtown of São Paulo
Table 4. Ambiental levels of HCs in São Paulo (ppbv)

\begin{tabular}{cccc}
\hline Compound & \multicolumn{3}{c}{ Year } \\
& $1995-1996^{\mathrm{a}}$ & Nov. 1998 $^{\mathrm{b}}$ & Aug. 2003 \\
\hline n-Hexane & - & 2.0 & - \\
n-Heptane & 2.7 & 1.2 & $0.32 \pm 0.19$ \\
Benzene & 5.2 & 2.6 & $2.72 \pm 1.37$ \\
Toluene & 7.4 & 9.0 & $7.46 \pm 3.36$ \\
Ethylbenzene & 1.4 & 2.0 & $0.68 \pm 0.41$ \\
m+p-Xylene & 4.2 & 4.6 & $1.20 \pm 0.76$ \\
o-Xylene & 1.4 & 1.5 & $0.55 \pm 0.44$ \\
1,3,5-TMB & 0.6 & - & $2.19 \pm 1.53$ \\
\hline
\end{tabular}

${ }^{\mathrm{a}}$ Ref. 3. ${ }^{\mathrm{b}}$ Ref. 4. ${ }^{\mathrm{c}}$ from this work - August of 2003.

on human health due to their toxicity.

Other important aspect that should be considered is the VOCs influence on ozone formation. A parameter used to quantify the contribution of VOCs on ozone formation is the MIR (Maximum Incremental Reactivity) scale, which represents the mass of ozone formed per gram of VOC emitted to the system. ${ }^{6,16-19}$ Aldehydes, specially acetaldehyde and formaldehyde and xylenes, for example have high potential of ozone formation and have great influence on ozone levels in urban atmosphere.

Table 5 resumes the mean concentrations of formaldehyde and acetaldehyde in São Paulo atmosphere, reported in the literature, including those found in this study. The levels of these two important species decreased when compared to previous values (from 1988), mainly for acetaldehyde and it can be due to the large decrease of the fleet that runs on ethanol - the maximum number of vehicles that used ethanol was reached in the late 1980s, accounting for approximately $90 \%$ of total new car sales in 1986. From then on, the sales of car that use only ethanol have decreased and about $17 \%$ of the fleet produced in 2004 use ethanol as fuel (statistics provided by Brazilian Automotive Industry, 2004 - ANFAVEA - public domain information. However, a large increase in the selling of flex-fuel cars (burning ethanol or gasohol) has occurred recently. Additionally the control of emissions of aldehydes for new cars contributed to this decrease. This can be shown with the change of acetaldehyde/ formaldehyde ratio, from higher than 1, measured in 1990s to a ratio in general lower than 1 (mean of $0.63 \pm 0.28$ in this work). ${ }^{21}$

Another important point to be considered is the increase of carburning natural gas. Studies performed in Rio Janeiro showed that the natural gas contribute with increase of formaldehyde concentrations. ${ }^{22}$ Although it is known that natural gas emitt less $\mathrm{CO}, \mathrm{HC}$ and particulate matter.

In general, most measurements of aldehydes around the world, presented a ratio that range from 0.3 to 0.8 (lower than 1 ). ${ }^{23}$ For almost all the literature values, the acetaldehyde/formaldehyde ratios measured in Brazil before the year 2000 were greater than $1 .{ }^{24}$ The great and constant change of vehicle types and fuel in Brazil it makes necessary frequent measurements of pollutants emission and ambient air quality monitoring. 
Table 5. Ambient levels of formaldehyde and acetaldehyde in São Paulo (ppbv)

\begin{tabular}{|c|c|c|c|}
\hline Location and date & Formaldehyde & Acetaldehyde & $\begin{array}{c}\text { Ratio, } \\
\text { acetaldehyde/ } \\
\text { formaldehyde }\end{array}$ \\
\hline $\begin{array}{l}\text { University of } \\
\text { São Paulo, Jun-Jul } \\
1986\end{array}$ & 8.8 & 7.6 & 0.86 \\
\hline $\begin{array}{l}\text { CETESB, Jul } \\
1986\end{array}$ & 13.5 & 8.0 & 0.59 \\
\hline $\begin{array}{l}\text { Post office } \\
\text { Square, Oct. } 1986\end{array}$ & 5.4 & 16.1 & 3.0 \\
\hline Congonhas, 1988 & 16.5 & 30.6 & 1.85 \\
\hline $\begin{array}{l}\text { Congonhas, } \\
\text { Set.-Oct. } 1989\end{array}$ & 10.8 & 22.3 & 2.06 \\
\hline $\begin{array}{l}\text { University of } \\
\text { São Paulo, Jul } \\
1989\end{array}$ & 4.5 & 10.5 & 2.33 \\
\hline $\begin{array}{l}\text { Cerqueira Cesar, } \\
\text { Marc-April } 1990\end{array}$ & 15.5 & 24.3 & 1.56 \\
\hline $\begin{array}{l}\text { Cerqueira Cesar, } \\
\text { Aug. } 1990\end{array}$ & 21.8 & 27.3 & 1.25 \\
\hline Mooca, 1993 & 4.2 & 6.1 & 1.45 \\
\hline $\begin{array}{l}\text { Cerqueira Cesar, } \\
1993\end{array}$ & 7.6 & 10.6 & 1.39 \\
\hline $\begin{array}{l}\text { Cerqueira Cesar, } \\
\text { Oct. } 1996 \text { - Jan. } \\
1997\end{array}$ & 5.4 & 7.5 & 1.39 \\
\hline $\begin{array}{l}\text { University of } \\
\text { São Paulo, Oct. } \\
\text { 1996-Jan. } 1997\end{array}$ & 1.3 & 2.8 & 2.15 \\
\hline $\begin{array}{l}\text { University of } \\
\text { São Paulo, Jul - } \\
\text { Sept } 1997\end{array}$ & 7.0 & 11.7 & 1.67 \\
\hline $\begin{array}{l}\text { Cerqueira Cesar, } \\
\text { Jul - Sep. } 1997\end{array}$ & 4.2 & 9.2 & 2.19 \\
\hline $\begin{array}{l}\text { At the border of } \\
\text { the São Paulo } \\
\text { University cam- } \\
\text { pus - Feb.1998 }\end{array}$ & $1.4-9.7$ & $1.0-10.2$ & $0.71-1.05$ \\
\hline $\begin{array}{l}\text { São Paulo, } \\
\text { Aug. } 1999\end{array}$ & $1.05-46.7$ & $1.2-56.6$ & $0.79-2.72$ \\
\hline This work, 2003 & $4.4 \pm 2.0$ & $2.8 \pm 2.2$ & 0.64 \\
\hline
\end{tabular}

Source: Ref. 21; Ref. 20; Ref. 22; Ref. 5

\section{CONCLUSIONS}

The goals of the analysis presented here, were to quantify the main VOCs emitted by vehicular fleet that have harmful effects on human health and also have high potential for ozone production. In addition a comparison with previous values reported in literature was performed. The concentration of selected HCs presented no decrease, but due to the few values reported in literature and associated to different characteristics of studies (sampling location, sampling duration, weather condition and others) it is difficult to evaluate. However the aldehydes concentrations decreased when compared to previous values (from 1988), mainly for acetaldehyde. There is a lack of information concerning the behavior of hydrocarbons in São Paulo. Only two air quality stations have NMHC monitors, due to difficulties and costs of measuring different hydrocarbons, thus only few experiments are performed in the area. The data presented here is compared to the previous data, which is very scarce.

The profile of HCs and aldehydes (formaldehyde and acetaldehyde mainly) were very close to traffic conditions indicating that the main source of VOCs in São Paulo is vehicular, as already reported.

\section{ACKNOWLEDGMENTS}

The authors acknowledge the Fundação de Amparo à Pesquisa do Estado de São Paulo (FAPESP) for funding this research (grants No. 02/09060-1 of first author). R. Astolfo and all the participants are acknowledged for experimental work. Thanks to Mackenzie for providing the place for the measurements. Additionally the authors acknowledge the São Paulo State Agency for Environmental Protection - CETESB for provide the data.

\section{REFERENCES}

1. CETESB; Série Relatórios/CETESB, São Paulo, 2006.

2. Molina, M. J.; Molina, L. T.; J. Air Waste Manag. Assoc. 2004, 54, 644.

3. Gee, I. L.; Sollars, C. J.; Chemosphere 1998, 36, 2497.

4. Colón, M.; Pleil, J. D.; Hartlage, T. A.; Guardani, M. L.; Martins, M. H.; Atmos. Environ. 2001, 35, 4017.

5. Montero, L.; Sanchez-Ccoyllo, O. R.; Vasconcellos, P. C.; Souza, S. R.; Pires, M.; Andrade, M. F.; Carvalho, L. R. F.; Environ. Sci. Technol. 2001, 35, 3071.

6. Grosjean, E.; Rasmussen, R. A.; Grojean, D.; Atmos. Environ. 1998, 32, 3371.

7. Gurjar, B. R.; Lelieveld, J.; Atmos. Environ. 2005, 39, 391.

8. Albuquerque, E. L. de; Andrietta, L. C. G.; Souza, K. R. P. de; Tomaz, E.; Resumos da Air Pollution XII, Rhodes, Grécia, 2004.

9. Pisani, S. O.; Bruns, R. E.; Vasconcellos, P. C.; Carvalho, L. R. F.; J. Environ. Monit. 2003, 5, 795 .

10. Souza, S. R.; Vasconcellos, P. C.; Mantovani, W.; Carvalho, L. R. F.; Revista Brasil Botânica 2002, 25, 413.

11. Oliveira, A. P.; Machado, A. J.; Escobedo, J. F.; Soares, J.; Theory Applied Climatology 2002, 71, 231.

12. Oliveira, A. P.; Bornstein, R. D.; Soares, J.; Water, Air, Soil Pollut. 2003, 3,3 .

13. Martins, L. D.; Andrade, M. F.; Freitas, E. D.; Pretto, A.; Gatti, L. V.; Albuquerque, E. L; Tomaz, E.; Guardani, M. L.; Martins, M. H. R. B.; Junior, O. M. A.; Environ. Sci. Technol. 2006, 40, 6722.

14. Nelson, P. F.; Quigley, S. M.; Atmos. Environ. 1983, 18, 79.

15. Monod, A.; Sive, B. C.; Avino, P.; Chen, T.; Blake, D. R.; Rowland, F.S.; Atmos. Environ. 2001, 35, 135.

16. Bowman, F. M.; Seinfeld, J. H.; Programmer Energy Combustion Science 1995, 21, 387

17. Carter, W. P. L.; Preliminary Report to California Air Resources Board 1998, Contract No. 95-308.

18. Hsu, Y., Tsai, J.; Chen, H., Lin, W.; Chemosphere 2001, 42, 227.

19. Hsieh, W.; Chen, R.; Wu, T., Lin, T.; Atmos. Environ. 2002, 36, 403.

20. Andrade, M. V. A. S.; Pinheiro, H. L. C.; Pereira, P. A. de P.; de Andrade, J. B.; Quim. Nova 2002, 25, 1117.

21. Grosjean, D.; Grosjean, E.; Moreira, L. F. R.; Environ. Sci. Technol. 2002, 36, 1389.

22. Corrêa, S. M.; Arbilla, G.; Atmos. Environ. 2005, 39, 4513.

23. Nguyen, H. T.; Takenaka, N.; Bandow, H.; Maeda, Y.; Oliva, S. T.; Botelho, M. M. F.; Tavares, T. M.; Atmos. Environ. 2001, 35, 3075.

24. Corrêa, S. M.; Martins, E. M.; Arbila, G.; Atmos. Environ. 2003, 37, 23. 